\title{
Optimalisasi Blended Learning Berbantuan Google Classroom untuk Meningkatkan Kualitas Pembelajaran di Sekolah Dasar
}

\author{
${ }^{*}$ Wahyu Nugroho', Angga Setiawan'2, Bima Nur Romadhoni ${ }^{3}$ \\ 1,2,3 STKIP PGRI Trenggalek, Trenggalek, Indonesia
}

\begin{tabular}{l}
\hline A) Check for updates \\
\hline Informasi Artikel \\
\hline Riwayat Artikel: \\
Diterima: 30 Oktober 2021 \\
Revisi Akhir: 09 November 2021 \\
Disetujui: 19 Desember 2021 \\
Terbit: 31 Desember 2021 \\
\hline Kata Kunci: \\
Blended Learning \\
Google Classroom \\
Kualitas Pembelajaran \\
\end{tabular}

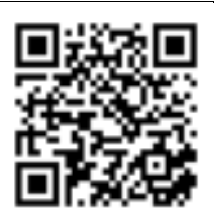

DOI: https://doi.org/10.53621/jippmas.v1i2.64 \begin{abstract}
ABSTRAK
Sebagai bentuk kesadaran dalam mengoptimalkan pembelajaran pada masa peralihan setelah pandemi covid-19 para pendidik perlu mengambil peran lebih awal untuk meningkatkan kualitas pembelajaran di sekolah dasar dengan mengadakan pelatihan dalam bentuk pengabdian masyarakat. Tujuan pengabdian ini adalah upaya nyata untuk mengoptimalkan pembelajaran blended learning berbantuan learning system managemen Google Classroom untuk meningkatkan kualitas pembelajaran guru dengan menjalin kerjasama sesuai dengan instansi sasaran. Kegiatan pelatihan ini ada karena kondisi di satuan pendidikan yang belum pernah tersentuh pelatihan dalam peningkatan kualitas pembelajaran blanded berbantuan LMS. Metode yang digunakan dalam pengoptimalisasi pembelajaran blanded adalah cermah, diskusi, praktik implementasi aplikasi Google Classroom yang terakomodasi dengan face to face home visit (blended). Sasaran Pengabdian masyarakat ini meliputi pendidik dan tenaga kependidikan di SDN 1 Ngares dan SDN 2 Ngares kabupaten Trenggalek sejumlah 15 guru, 2 operator dan 3 staf karyawan sekolah. Hasil akhir yang didapatkan dari kegiatan pengabdian masyarakat meningkatkan keterampilan guru dalam mengoptimalkan blanded learning berbantuan google classroom, sehingga nantinya memberikan dampak positif terhadap kualitas pembelajaran guru.
\end{abstract}

\section{PENDAHULUAN}

Perkembangan teknologi dan informasi di Indonesia semakin pesat berkembang dari setiap tahunnya, hal ini tidak dapat dihindari mengingat kebutuhan dan tuntutan perkembangan manusia semakin kompleks yang berdampak secara tidak langsung dalam berbagai bidang, salah satunya dalam bidang pendidikan. Era revolusi industry 4.0 menjadikan literasi digital sebagai ujung tombak, terlebih peran guru yang tidak dapat lepas dari perkembangan teknologi dalam proses pembelajaran. Oleh sebab itu pemanfaatan pembelajaran dengan mengoptimalkan pemahaman teknologi berbasis learning managemen system dapat mendorong terbentuknya pembelajaran yang lebih inovatif, kreatif dan aktif (Nugroho, 2021b). Perkembangan teknologi mengharuskan guru mampu memahami dan mengimplementasikan kepada peserta didik agar pembelajaran tidak membosankan, terlebih jika guru menggunakan teknologi peserta didik cenderung termotivasi dalam pembelajaran, hal ini nantinya juga berdampak pada kewajiban sekolah untuk menerapkan pemanfaatan teknologi digital (Siregar \& Marpaung, 2020).

Implementasi pembelajaran dengan LMS (Learning Management System) sangat mendukung terlebih kondisi saat pandemi covid yang memberikan pembatasan aktivitas pembelajaran. Dengan pembelajaran jarak jauh melalui media dalam jaringan atau yang disebut daring seorang guru diharapkan tetap melanjutkan aktivitas pembelajaran untuk mendidik dan membimbing peserta didiknya. Sesuai dengan kebijakan menteri pendidikan dan kebudayaan Nomor 4 tahun 2020 yang diperkuat dengan surat edaran 
Optimalisasi Blended Learning Berbantuan Google Classroom untuk Meningkatkan Kualitas Pembelajaran di Sekolah Dasar

Sesjen Nomor 15 tahun 2020 tentang Pedoman pelaksanaan pembelajaran selama darurat covid-19. Upaya yang mendukung pembelajaran daring telah banyak dilakukan salah satunya dengan menggunakan aplikasi google classroom. Aplikasi google classroom itu sendiri membantu guru untuk membuat materi, mengatur tugas kelas dengan cepat dan mudah, memberikan umpan balik kepada siswa langsung secara efisien, dan berkomunikasi bersama siswa tanpa terbatas oleh ruang dan waktu (Hapsari \& Pamungkas, 2019).

Pembelajaran daring apabila diterapkan secara berkelanjutan dan terus menerus tanpa adanya dukungan dari sarana prasana yang memadai dan peran dari orang tua untuk memberikan dukungan secara materi dan psikologi kepada anak akan menimbulkan permasalahan yang besar dalam proses pendidikan. Walaupun demikian tidak selamanya pandemi terus berlangsung, oleh sebab itu sekolah bisa mengantisipasi dengan menerapkan pembelajaran Blanded Learning. Proses pembelajaran yang menggabungkan antara pembelajaran tatap muka dengan e-learning dalam menggunakan media pembelajaran termasuk dalam pembelajaran Blanded learning (Wardani et al., 2018).

Berdasarkan hasil wawancara tim kepada guru, para guru mengiginkan pembelajaran daring dengan menggunakan LMS namun kesulitan mengaplikasikannya, selain itu guru merasa kesulitan mengidentifikasi karakter anak apabila tidak bertemu secara tatap muka. Maka dari itu metode home visit juga bisa memberikan kesempatan kepada guru untuk bisa menerapkan pembelajaran langsung. Metode ini dapat menyelesaikan berbagai kondisi masalah terkait proses pembelajaran dengan kerjasama yang baik antara seorang guru dan orang tua dalam mendidik dan membimbing peserta didik, sehingga akan membuat proses pendidikan akan lebih bermakna pada saat pandemi covid-19 (Ibda \& Laeli, 2021). Proses pembelajaran akan lebih efektif, efisien, kondusif dan terarah secara baik dengan menggunakan blended learning.

Blanded learning juga bisa di artikan sebagai pembelajaran dengan secara online dan face to face baik satu persatu maupun dalam kelompok kecil (Inayah, 2020). Permasalahan yang sering terjadi berdasarkan tinjauan pustaka yaitu sinyal internet yang kurang stabil saat digunakan dalam pembelajaran daring dan beberapa orang tua merasa mengeluh karena pembelajaran secara daring juga membatasi ruang gerak aktivitas dalam kesehariaannya, karena harus menunggu anaknya untuk mengikuti proses pembelajaran secara daring. Proses pembelajaran secara daring akan lebih maksimal dan efektif apabila dijadikan pembelajaran itu secara blended (Lestaria Simvony et al., 2021).

Secara sederhana, blended learning diartikan sebagai penggabungan pembelajaran langsung secara tatap muka dengan pembelajaran online (Ni'matul Khoiroh, Munoto, 2017). Dengan pengoptimalkan pembelajaran secara blanded diharapkan dapat memberikan keberhasilan pendidik untuk memberikan kontribusi dalam segi kemandirian bagi peserta didik. Tujuan blended learning sendiri antara lain Membantu pendidik untuk berkembang lebih baik didalam proses belajar dan menyediakan peluang yang praktis realistis bagi guru dan peserta didik (Amin, 2017).

Berdasarkan uraian kondisi diatas tim pengusul bersama mitra perlu mengadakan kerjasama dalam memanfaatkan Perkembangan teknologi dalam kegiatan pelatihan. Dengan mengoptimalkan pembelajaran blanded yang berbantuan google classroom diharapkan guru sebagai pendidik dapat meningkatkan kualitas pembelajarannya. 
Optimalisasi Blended Learning Berbantuan Google Classroom untuk Meningkatkan Kualitas Pembelajaran di Sekolah Dasar

\section{PERMASALAHAN}

Berdasarkan analisis situasi yang diobservasi oleh tim penyusul kondisi mitra untuk sarana dan prasarana dalam proses pembelajaran disaat pandemi covid-19 sangat mendukung karena di sekolah tersebut sudah menyediakan wifi dan komputer akan tetapi didalam penerapan proses pembelajaran secara daring masih ditemukan permasalahan-permasalahan yang membuat kurang optimalnya proses pembelajaran. Permasalahan guru kurang memahami aplikasi online berbasis LMS (Learning Managemen System) yang bisa digunakan untuk diskusi dengan siswa, memberikan umpan balik kepada siswa secara efisien, mengelola dan tempat untuk mengumpulkan tugas serta memberikan penilaian secara langsung (Nugroho, 2021a).

Hasil wawancara tim dengan Kepala Sekolah SDN Ngares penggunaan aplikasi untuk menerapkan proses pembelajaran secara daring yang dilakukan oleh guru hanya menggunakan aplikasi Whatsapp. Sehingga perlu adanya solusi untuk mempermudah proses pembelajaran secara daring dan pengelolaan tugas dengan menggunakan aplikasi google classroom. Disisi lain Kepala Sekolah SDN Ngares memberikan informasi bahwasannya beberapa peserta didik tidak bisa mengikuti pembelajaran secara daring karena faktor sinyal internet yang tidak bisa diakses dan beberapa orang tua dengan status ekonomi yang kurang tidak bisa membelikan kouta internet yang digunakan untuk pembelajaran daring, beberapa siswa yang karena kendala faktor tersebut mereka rela datang ke sekolah setiap hari untuk bisa mengikuti proses pembelajaran langsung, tetapi karena masih pandemi covid-19 maka proses pembelajaran secara tatap muka masih belum diijinkan oleh pemerintah. Maka dari itu dibutuhkan metode home visit yang nantinya memberikan keringanan kepada peserta didik, sesuai pendapat (Purwanto, 2021) metode home visit dapat memberikan bimbingan belajar dan motivasi secara langsung dari seorang guru.

Desa Ngares Kabupaten Trenggalek berada di zona kuning sesuai dengan data dari Satuan Gugus Tugas Percepatan Penanganan COVID-19 Jawa Timur, dengan melihat surat Keputusan Bersama Menteri Nomor 440-882 Tahun 2020 maka pembelajaran secara tatap muka bisa dilakukan dengan sangat terbatas dan tetap mematuhi protokol kesehatan apabila daerah tersebut sudah berada di zona kuning atau hijau. Hasil wawancara dari beberapa guru di SDN Ngares, mereka mengiginkan pembelajaran bisa dilakukan secara tatap muka karena mereka sendiri merasa kesulitan mengidentifikasi karakter anak apabila tidak bertemu secara tatap muka dan penjelasan materi beberapa kurang dipahami oleh peserta didik disaat pembelajaran daring. Maka dari itu metode home visit disini juga bisa memberikan kesempatan kepada guru untuk bisa menerapkan pembelajaran langsung kepada peserta didik (Ibda \& Laeli, 2021). Proses pembelajaran dirasa akan lebih sangat efektif, efisien, kondusif dan terarah secara baik dengan menggunakan blended learning ini.

Melihat permasalahan yang ada dan kebermanfaatan google classroom dengan dipadukan dengan metode home visit, pengabdian ini ingin mensosialisasikan penggunaan aplikasi google classroom dan metode home visit dalam proses pembelajaran tematik pada guru-guru di SDN Ngares Trenggalek. Adapun tujuan pengabdian ini adalah penerapan google classroom dengan dipadukan dengan metode home visit secara face to face tatap muka dalam proses pembelajaran tematik. Hal ini bertujuan pada pemanfaatan goole classroom dengan metode home visit dalam mata 
Optimalisasi Blended Learning Berbantuan Google Classroom untuk Meningkatkan Kualitas Pembelajaran di Sekolah Dasar

pelajaran tematik, yang secara lebih luas lagi adalah untuk mengembangakan aspek kognitif, afektif dan psikomotorik peserta didik.

\section{METODE PELAKSANAAN}

Kegiatan dalam pelatihan sebagai bentuk pengabdian masyarakat yang dilaksanakan di aula SD Negeri Ngares terdiri dari unsur KKG (kelompok kerja guru) dan juga SD sekitar kecamatan Trenggalek dilaksanakan selama 4 hari dengan jumlah peserta 20 peserta. Selama kegiatan kerjasama dalam pengabdian masyarakat ini dibagi menjadi 2 sesi yakni 2 hari sebagai pemaparan konsep dan teoritis dari LMS Google Classroom, dan 2 hari sebagai pengaplikasian terapan dengan perangkat gawai dan komputer baik dalam penggunaan sebagai guru atau sebagai siswa. Selain penguasaan teknologi dalam penggunaan LMS Google Classroom guru juga dibekali dengan metode home visit yang nantinya diarahkan dalam bentuk kelompok kecil dalam pelaksanaan pembelajaran.

Melalui kegiatan ini diharapkan dapat meningkatkan penguasaan teknologi serta kualitas pembelajaran baik saat pandemi ataupun setelah pandemi berakhir (Ketut, 2018), dari hal tersebut besar harapan guru dapat memberikan pengalaman pada pendidik dan peserta didik dalam berkolaborasi bersama. Sehingga fokus dari pengabdian masyarakat ini adalah para pendidik dan juga staf operator sekolah di gugus kerja SD Negeri Ngares Trenggalek. Adapun rincian dalam tahapan pelatihan ini meliputi tahap persiapan yang mencangkup penentuan lokasi dan sasaran pelatihan, kemudian pada tahap pelaksanaan meliputi metode cara yang digunakan seperti ceramah, tanya jawab dan praktik pengoperasioan LMS Google Classroom baik sebagai guru ataupun sebagai siswa.

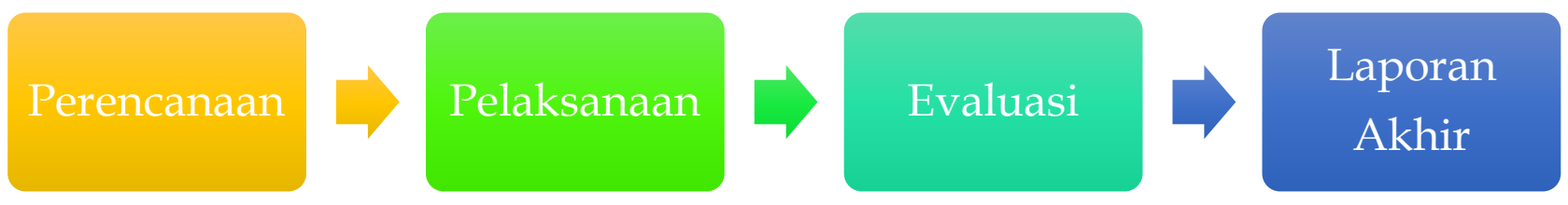

Gambar 1. Bagan pelaksanaan pengabdian kepada masyarakat di SD Negeri Ngares

\section{PELAKSANAAN}

Pelaksanaan program pengabdian masyarakat yang terintegrasi dengan program kerjasama bersama mitra kampus menjadi wadah untuk mengembangkan potensi diri pendidik dalam meningkatkan kualitas pembelajaran serta dapat di interpretasikan sebagai bentuk implementasi tri dharma perguruan tinggi bagi tim pengagas. Kegiatan pelatihan ini dilaksanakan selama 4 hari mulai tanggal 18,19,21,22 bulan Juni 2021 dengan jumlah peserta 20 yang terdiri dari 15 guru, 2 operator sekolah dan 3 staf karyawan yang tergabung dalam kelompok kerja guru (KKG) Gugus Ngares Kecamatan Trenggalek. Dari usia peserta cukup bervariatif dengan kolaborasi lintas generasi para guru senior antusian dalam melaksanakan diskusi tanya jawab dan praktik dalam pelaksanaannya.

Pelatihan diawali dengan perwakilan sambutan dari mitra dan tim pengagas sebagai bentuk pembukaan kegiatan, kemudian dilajutkan dengan menjelaskan kompoten dengan pengenalan LMS Google Classroom beserta cara pengoperasiannya dalam proses pembelajaran secara blanded learning. Learning Managemen System merupakan perangkat yang digunakan secara online dalam membantu pelaksanaan pembelajaran 
Optimalisasi Blended Learning Berbantuan Google Classroom untuk Meningkatkan Kualitas Pembelajaran di Sekolah Dasar

jarak jauh (El Fauziah et al., 2019). Komponen item yang ada dalam LMS memuat pembuatan kelas, pengisian forum diskusi, pengumpulan tugas/penugasan, anggota kelas (siswa), umpan balik serta penilaian.

Kombinasi dalam pembelajaran blanded learning sangat ideal bagi guru terlebih saat penerapan pembelajaran dengan skala terbatas dengan berbantuan aplikasi berbasis web seperti LMS Google Classroom, sebab blanded learning mampu menggabungkan antara pembelajaran tatap muka langsung dengan pembelajaran berbasis pendekatan teknologi. Pembelajaran dengan pendekatan teknologi yang dimaksud adalah dengan mengkombinasikan sumber-sumber pembelajaran yang dimuat ke dalam tampilan website LMS Google Classroom, dengan akses bisa melalui handphone, laptop, komputer atau PC serta media yang berbasis elektronik.

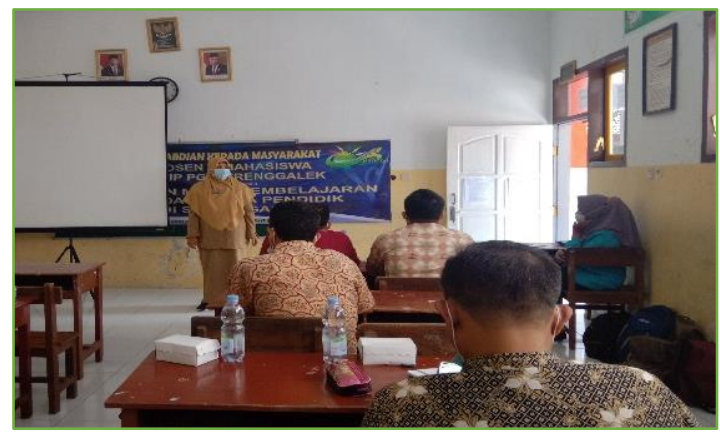

Gambar 1.Pembukaan Acara

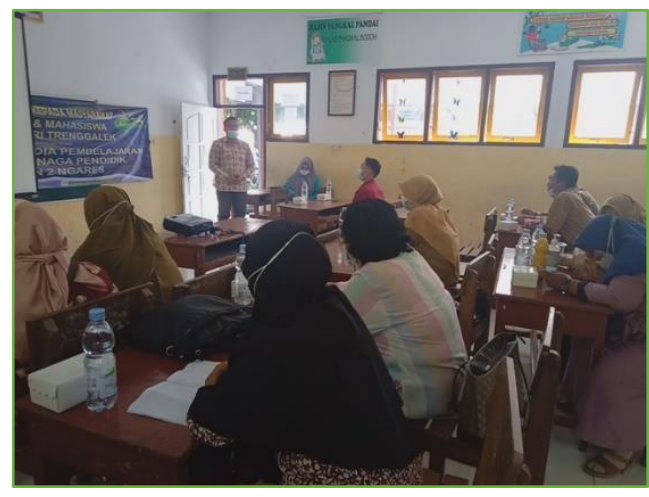

Gambar 2.Pembukaan Kegiatan Pelatihan

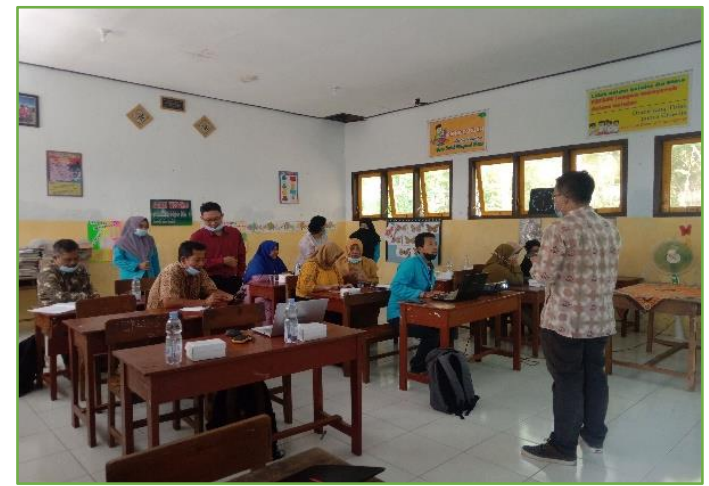

Gambar 3.Proses ceramah dan tanya jawab

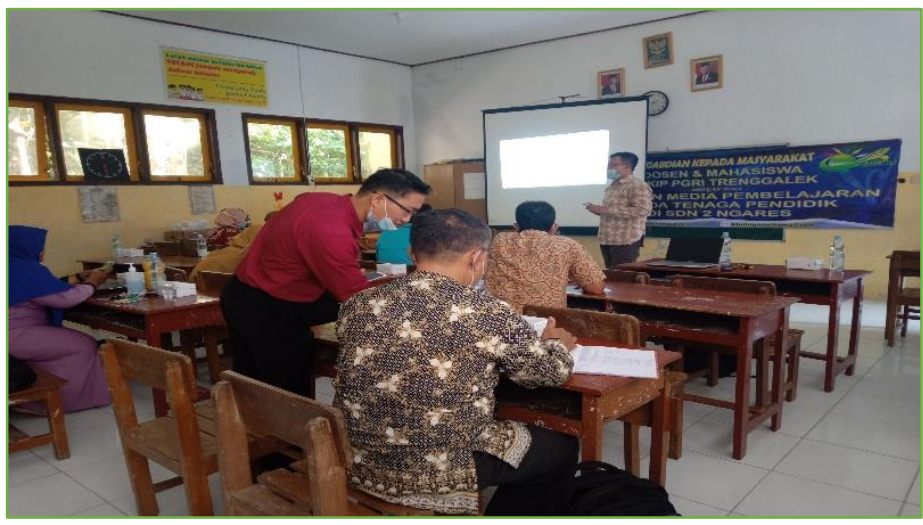

Gambar 4.Praktik Pendampingan Pelatihan 
Kegiatan pelatihan berlangsung cukup kooperatif dan antusias, guru merasa terbantu dengan adanya kegiatan pelatihan dengan berbagai metode yang digunakan pengagas seperti ceramah, tanya jawab/diskusi dan peninjauan praktik langsung, hal ini dilaksanakan untuk mewujudkan upaya nyata dalam membantu guru mewujudkan pengoptimalisasi pembelajaran blanded learning untuk meningkatkan kulitas pembelajaran yang dilaksanakan guru.

\section{HASIL DAN DISKUSI}

Pembelajaran dengan menerapkan blanded learning secara optimal diharapkan mampu meningkatkan kualitas pembelajaran yang dilaksanakan oleh pendidik, selain itu peserta didik akan lebih mudah melaksanakan pembelajaran di tengah pandemi covid yang berlangsung pasang surut. Kehadiran pendidik akan seimbang jika penerapan blanded learning mampu di optimalkan dengan LMS Google Classroom yang nantinya dipadukan dengan metode home visit yang masuk pada bagian face to face (Sofiana, 2015). Selain itu Google Classroom menjadi jalur alternatif untuk mendukung pembelajaran secara blanded, layanan LMS merupakan bagian dari produk G suite Education yang bisa di akses tanpa ada biaya penggunaan (Susanti \& Prameswari, 2020).

Kegiatan pelatihan ini sebagai wujud bentuk kerjasama mitra antara sekolah dasar dengan kampus STKIP PGRI Trenggalek, selama pelatihan berlangsung banyak pendidik yang tertarik untuk lebih mendalami materi yang disampaikan dengan cara ceramah, tanya jawab dan praktik pengoperasian perangkat aplikasi berbasis web di google classroom sesuai pendapat (Hidayat et al., 2020) solusi mudah untuk memahamkan materi kepada seseorang melalui ceramah terlebih dahulu, setelah itu ada diskusi dan praktek sebagai alat ukur dari pemahaman seseorang tersebut. Motivasi pendidik muncul lebih kuat untuk memahami materi yang disampaikan pada saat melihat penjelasan tampilan materi dan kebermanfaatan LMS google classroom, walaupun belum begitu mengenal akrab jenis LMS tersebut, mengingat di sekitar sekolah dasar Ngares belum pernah ada pembinaan atau pelatihan berkelanjutan dalam upaya peningkatan kualitas pembelajaran.

Pada dasarnya pembelajaran blanded learning menjadi sebuh model pembelajaran baru agar nantinya seluruh peserta didik dapat masuk dan menyerap materi sebanyakbanyaknya dari proses pembelajaran (Jumaini dkk, 2021). Pembelajaran tersebut terdiri dari kombinasi pembelajaran e-learning dengan pembelajaran tatap muka atau face to face, hal ini bertujuan agar siswa mendapatkan pengalaman yang efektif serta efisien dalam pengkombinasian lingkungan pembelajaran yang berbeda. Pada kegiatan sesi penyampaian materi meliputi pemberian contoh tampilan website google classroom, adapun rincian dalam pengoperasional LMS Google Classroom sebagai berikut.

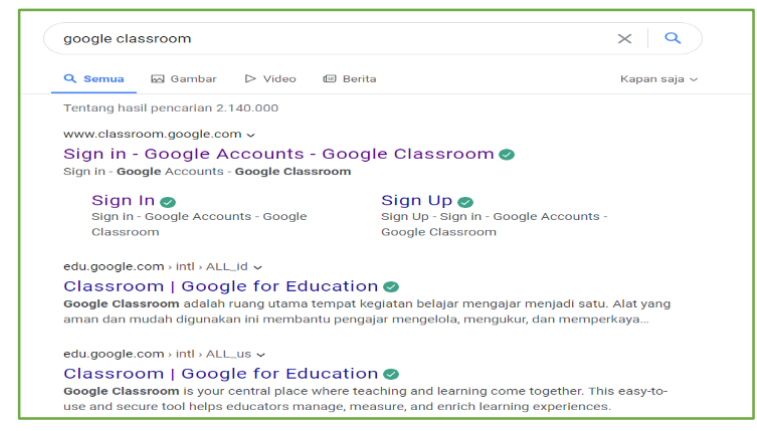

Gambar 1.Tampilan di mesin pencarian

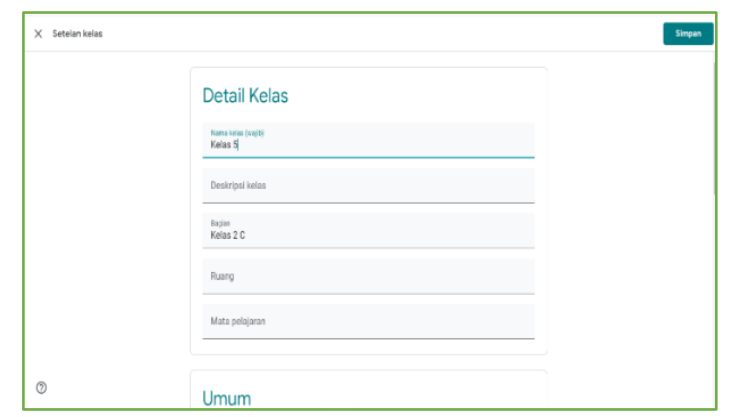

Gambar 2.Tampilan Pembuatan Detail Kelas 
Optimalisasi Blended Learning Berbantuan Google Classroom untuk Meningkatkan Kualitas Pembelajaran di Sekolah Dasar

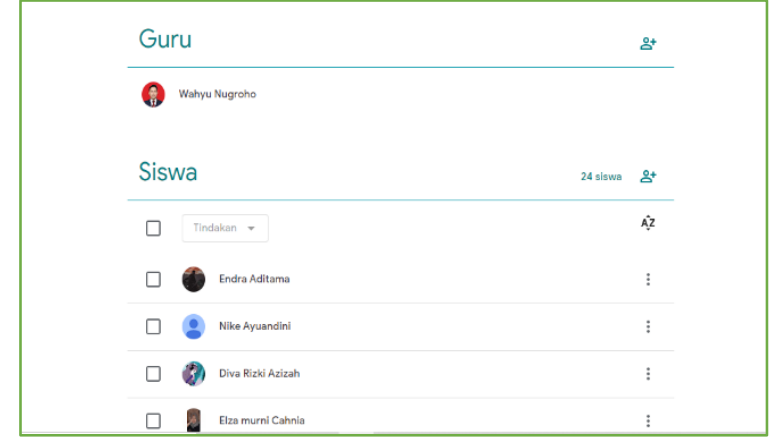

Gambar 3.Tampilan Daftar nama Siswa

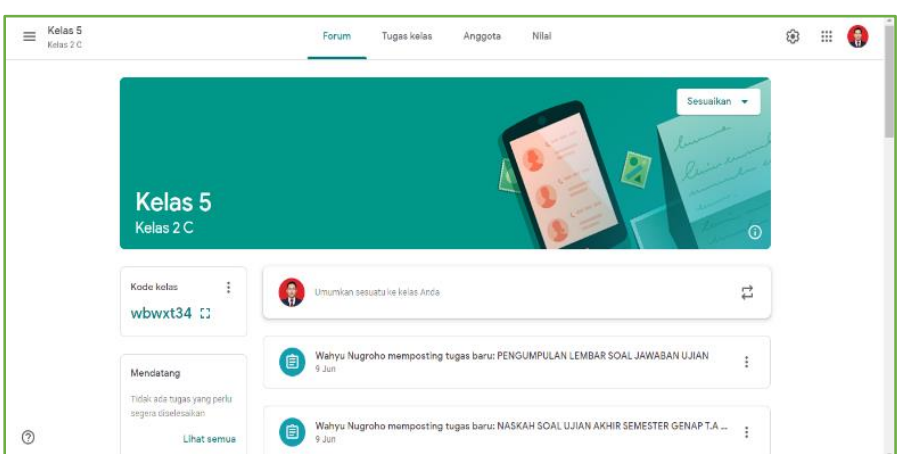

Gambar 4.Tampilan Forum Diskusi dan Penugasan

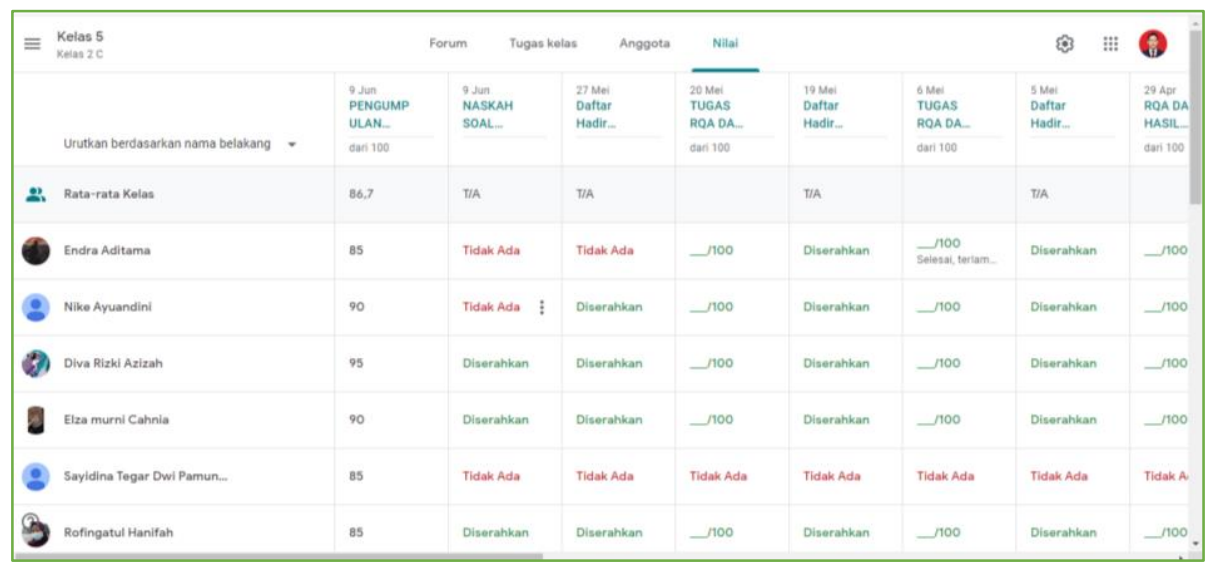

Gambar 5.Tampilan Hasil Penilaian

Peserta kegiatan ini langsung diberikan pengarahan dalam pembuatan kelas mulai dari awal praktik mencari kata kunci pencarian pada mesin Google, kemudian menentukan kelas berserta subtansi muatan di dalamnya, penentuan kelas disesuaikan dengan muatan materi sesuai tema dalam pertemuan per pembelajaran. Selanjutnya peserta juga mempraktikkan cara menambahkan siswa dalam kelas secara online dengan dua alternatif cara, sesuai pendapat (Salamah, 2020) yaitu yang pertama melalui link undangan, dan yang kedua melalui copy link yang langsung masuk dalam website.

Tahap selanjutnya adalah pemberian materi yang nantinya bisa dibaca dan dipahami oleh siswa, hasil pemberian materi di google classroom akan bisa diakses oleh siswa setiap harinya tanpa ada batasan, untuk materi yang belum dipahami oleh siswa terdapat laman untuk diskusi dengan gurunya yaitu forum diskusi google classroom setelah siswa memahami materi dan diskusi selesai langkah selanjutnya pemberian tugas yang nantinya akan di cek, dikerjakan langsung dan dikirim oleh siswa melalui laman pengiriman tugas serta penilaian setiap proses pembelajaran yang telah disesuaikan dengan kebutuhan pembelajaran (Sriyani, 2021). Semua rangkaian kegiatan tersebut dilakukan selama 4 hari secara penuh, sebab keterbatasan waktu akan menyebabkan kesalahan dalam memahami pengoperasian Learning Managemen System pada Google Classroom.

Hakikat dari pembelajaran kombinasi yang sering disebut dengan blanded learning setidaknya perlu adanya pendampingan bersama saat pelaksanaanya, berdasarkan 
Optimalisasi Blended Learning Berbantuan Google Classroom untuk Meningkatkan Kualitas Pembelajaran di Sekolah Dasar

pernyataan (Sofiana, 2015) saat implementasi blanded learning setidaknya memperhatian 6 hal yakni:

1. Penyampaian bahan ajar secara konsisten agar siswa paham dengan informasi yang telah diberikan;

2. Penyelenggaraan pembelajaran blanded wajib dilaksanakan secara serius;

3. Penggunaan bahan ajar pendidik harus keterbaruan yang terupdate baik isi maupun formatnya serta ketersediaan bahan ajar;

4. Pembagian alokasi waktu merujuk pada perbandingan 75 : 25 dalam arti $75 \%$ sebagai pembelajaran daring atau online sedangkan $25 \%$ sebagai pembelajaran tatap muka atau face to face;

5. Pembagian alokasi $25 \%$ di khususkan pada siswa yang mengalami kendala/ permasalahan dalam memahami materi selama proses pembelajaran;

6. Pelaksanaan blanded learning perlu adanya kedisiplinan dalam hal pembagian waktu serta pemberian perhatian secara terus menerus secara berkelanjutan, agar peserta didik merasakan peningkatan pemahaman, sehingga pendidik secara langsung dapat meningkatkan kualitas pembelajaran.

Setelah peserta pelatihan memahami langkah-langkah pembelajaran blanded yang dibahas secara teoritis dan konseptual menggunakan metode ceramah kemudian dilanjutkan dengan pemberian materi penggunaan Learning Managemen System pada Google Classroom dengan durasi waktu selama 2 hari pada hari pertama dan kedua, selanjutnya di hari ke 3 dan 4 peserta kegiatan melaksanakan praktik langsung dengan pembukaan secara umum terkait materi yang telah dibahas pada hari sebelumnnya.

Selama kegiatan praktik ada pendampingan dari narasumber secara langsung untuk memantau perkembangan pendidik, dihari ke tiga sebagian pendidik ada yang sudah mampu dan sebagian kurang memahami pengoperasian google classroom itu sendiri, secara bertahap narasumber dan tim memberikan arahan atau bimbingan secara perlahan untuk mengoptimalkan pemahaman pendidik dalam pengoperasian google classroom. Dihari keempat seluruh pendidik sudah memahami alur dalam pengoperasian google classroom, ada sebagian guru yang sudah mempraktekkan cara mengelola materi dan tugas, sesuai pendapat (Ucu, 2021) materi dan tugas di google classroom akan dikelola oleh guru serta nantinya dibagikan kepada siswa untuk langsung dikerjakan, setelah tugas dikumpulkan guru menilai tugas yang sudah dikirim oleh siswa tersebut.

Tampilan pada penilaian tugas siswa pada penggunaan Learning Managemen System Google Classroom akan terlihat nama siswa beserta foto yang digunakan dalam aplikasi, kemudian tanggal dan bulan pengiriman tugas serta jenis atau bentuk tugas yang di berikan oleh pendidik. Selain itu pendidik juga dipermudah untuk menyajikan hasil penilaian setiap pertemuan dalam aplikasi berbasis Learning Managemen System Google Classroom, menurut (Setyaningsih \& Hidayat, 2021) rentan nilai pada google classroom yaitu 0-100. Pendidik juga bisa mengecek secara langsung siswa yang belum tuntas dalam mengirimkan tugas atau siswa yang terlambat dalam pengiriman tugas melalui aplikasi website tersebut.

Selama proses pelatihan peserta yang cenderung kurang paham akan di kelompokkan bersama peserta yang sudah paham menjadi kelompok kecil, sebab pelatihan dengan melibatkan teman sejawat akan lebih mempermudah pemahaman peserta yang lain. Selanjutnya proses Keberhasilan pendidik khususnya guru dalam pelatihan ini bisa 
Optimalisasi Blended Learning Berbantuan Google Classroom untuk Meningkatkan Kualitas Pembelajaran di Sekolah Dasar

terlihat saat mereka mampu mengopersionalkan secara penuh Learning Managemen System pada Google Classroom, sehingga guru dapat dengan mudah membuat dan memanajemen kelas baik pengumpulan tugas, memberikan nilai dan umpan balik dari tugas siswa (Suryadi et al., 2020).

\section{KESIMPULAN}

Seluruh peserta pelatihan dalam upaya optimalisasi pembelajaran blanded learning berbantuan Learning Managemen System pada Google Classroom diharapkan dapat memfasilitasi guru untuk meningkatkan kualitas pembelajaran online, baik saat pandemi maupun setelah pandemi berakhir. Guru sekolah dasar yang bergabung dalam Kelompok Kerja Guru (KKG) dengan melibatkan unsur kepala sekolah dan operator sekolah telah mampu mengimplementasikan Learning Managemen System Google Classroom dari awal membuat kelas baru sampai membuat hasil penilaian terhadap siswa. Kegiatan pengabdian secara langsung akan memberikan kebermaknaan peserta untuk meningkatkan pemahamannya dalam melaksanakan pembelajaran blanded dengan berbantuan Learning Managemen System Google Classroom.

Berdasarkan hasil kegiatan pelatihan dalam rangka pengabdian kepada masyarakat perlu adanya saran keberlanjutan agar kualitas pembelajaran dapat dipertahankan yakni 1) perlu adanya tindak lanjut pengembangan dari implementasi pembelajaran blanded berbantuan Learning Managemen System pada Google Classroom, 2) Perlu adanya tindak lanjut dan pendampingan guru dalam mengimplementasikan Learning Managemen System pada Google Classroom, 3) Masih perlu adanya peningkatan dan pengembangan materi dalam pelatihan secara berkelanjutan untuk meningkatkan kualitas pembelajaran melalui Learning Managemen System pada Google Classroom, mengingat waktu yang disepakai bersama mitra terbatas. Sehingga nantinya perlu adanya tindakan tindak lanjut sebagai bahan evaluasi dan monitoring bersama dalam menumbuhkan kualitas pembelajaran.

\section{DAFTAR PUSTAKA}

Amin, A. K. (2017). Kajian Konseptual Model Pembelajaran Blended Learning berbasis Web untuk Meningkatkan Hasil Belajar dan Motivasi Belajar. Jurnal Pendidikan Edutama, 4(2), 51-64.

El Fauziah, U. N., Suryani, L., \& Syahrizal, T. (2019). Penerapan Google Classroom Dalam Pembelajaran Bahasa Inggris Kepada Guru-Guru Bahasa Inggris Smp Di Subang. Abdimas Siliwangi, 2(2), 183. https:/ / doi.org/10.22460/as.v2i2p183-191.3281

Hapsari, S. A., \& Pamungkas, H. (2019). Pemanfaatan Google Classroom Sebagai Media Pembelajaran Online Di Universitas Dian Nuswantoro. WACANA: Jurnal Ilmiah Ilmu Komunikasi, 18(2), 225-233. https:/ / doi.org/10.32509/wacana.v18i2.924

Hidayat, M. T., Junaidi, T., \& Yakob, M. (2020). Pengembangan Model Pembelajaran Blended Learning dalam Meningkatkan Pemahaman Siswa Terhadap Tradisi Lisan Aceh. 25(3), 401-410.

I Ketut Widiara. (2018). Blanded Learning sebagai Alternatif Pembelajaran di Era Digital. PURWADITA, 2(2), 50-56.

Ibda, H., \& Laeli, D. N. (2021). Hasil Belajar Siswa Saat Pandemi Covid-19 Melalui Home Visit Studi di MI Salafiyah Kranggan. At-Thullab: Jurnal Pendidikan Guru Madrasah Ibtidaiyah, 5(1), 12. https:/ / doi.org/10.30736/atl.v5i1.451

Ika Sriyani. (2021). Google classroom sebagai solusi pembelajaran jarak jauh mata 
Optimalisasi Blended Learning Berbantuan Google Classroom untuk Meningkatkan Kualitas Pembelajaran di Sekolah Dasar

pelajaran administrasi umum. Indonesian Journal of Education and Learning, 4(2), 456461. https:/ / doi.org/10.31002/ijel.v4i2.3111

Inayah, N. (2020). Keefektifan Metode Blended Learning Berbasis Multimedia Untuk Analisis Pemahaman Konsep Nurul Inayah Universitas Negeri Semarang Tahun 2020. Tesis. Program Studi Pendidikan Kimia Pascasarjana Universitas Negeri Semarang, $1-120$.

Jumaini, Hilda Hirmaliza Hertin, Mazruatun Nisfiyati, M. I. (2021). Penerapan Metode Pembelajaran Blanded Learning dalam Meningkatkan Pemahaman Konsep Hasil Belajar Siswa: Sebuah Meta-Analisis. Pembelajaran Matematika Dan Pembelakaran Matematika, 5(1), 48-63.

Lestaria Simvony, Y., Budi Santosa, A., \& Nugroho, W. (2021). The Role of Parents in Blended Learning Towards Student Character Values in The Covid-19 Pandemic. ZAHRA: Research and Tought Elementary School of Islam Journal, 2(2), 134-143. https:/ / doi.org/10.37812/zahra.v2i2.249

Ni'matul Khoiroh, Munoto, dan L. A. (2017). Pengaruh Model Pembelajaran Blended Learning Dan Motivasi Belajar Terhadap Hasil Belajar Siswa. Jurnal Penelitian Pendidikan, 10(Blended Learning), 97-110.

Nugroho, W. (2021a). Problematika Pemenuhan Hak Belajar Anak Di Era Pandemi Dari Sudut Pandang Guru, Siswa Dan Orangtua. In Adi Wijayanto (Ed.), Implementasi dan Problematika Merdeka Belajar (pp. 199-206). https:/ / files.osf.io/v1/resources/yshk6/providers/osfstorage/608a766c6801ab00 352abcfa?action=download\&direct\&version=1

Nugroho, W. (2021b). Strategi Guru Dalam Memanfaatkan Pembelajaranberbasis Digital Pada Kurikulum Darurat. In A Wijayanto (Ed.), Akademisi dalam lingkar daring. Akademia

Pustaka. https:/ / scholar.google.co.id/scholar?oi=bibs\&hl=id\&cluster=861132808226869711 9

Purwanto, R. (2021). Home Visit Method Dalam Upaya Meningkatkan Motivasi Belajar Siswa Sekolah Dasar. 8(1), 51-64.

Salamah, W. (2020). Deskripsi Penggunaan Aplikasi Google Classroom dalam Proses Pembelajaran. 4, 533-538.

Setyaningsih, W. D., \& Hidayat, S. (2021). Pedadidaktika: Jurnal Ilmiah Pendidikan Guru Sekolah Dasar Analisis Penggunaan Aplikasi Google Classroom Sebagai Media Pembelajaran Dalam Meningkatkan Keaktifan Siswa. 8(3), 727-741.

Siregar, Z., \& Marpaung, T. B. (2020). Pemanfaatan Teknologi Informasi dan Komunikasi (TIK) Dalam Pembelajaran di Sekolah. BEST Journal (Biology Education, Sains and Technology), 3(1), 61-69. https:/ / doi.org/10.30743/best.v3i1.2437

Sofiana, N. (2015). Implementasi Blended Learning Pada Mata Kuliah Extensive Listening. 12(1).

Suryadi, A., Rosa, N. M., \& Suaedah, S. (2020). Pelatihan Penggunaan Google Classroom sebagai Media Pembelajaran dan Google Form untuk Pembuatan Soal. Prosiding Seminar Nasional Pengabdian Kepada Masyarakat 2020 (SNPPM-2020), 2020, 176-184.

Susanti, D. I., \& Prameswari, J. Y. (2020). Adaptasi Blended Learning di Masa Pandemi COVID-19 untuk Pembelajaran Bahasa Inggris di Sekolah Dasar. Lingua Susastra, 1(2), 50-61. https:/ / doi.org/10.24036/1s.v1i2.8

Ucu Suhayati. (2021). Pengaruh Pembelajaran Daring dengan Menggunakan Aplikasi 
Optimalisasi Blended Learning Berbantuan Google Classroom untuk Meningkatkan Kualitas Pembelajaran di Sekolah Dasar

Google Class Room dan Motivasi belajar terhadap hasil belajar siswa. Jurnal Teknologi Pendidikan Dan Pembelajaran, 8(1), 1-16.

Wardani, D. N., J.E, A. T., \& Wedi, A. (2018). Daya Tarik Pembelajaran Di Era 21 Dengan Blended Learning Deklara Nanindya Wardani, Anselmus J.E. Toenlioe, Agus Wedi. 1(1), 13-18.

\footnotetext{
* Wahyu Nugroho, M.Pd (Corresponding Author)

STKIP PGRI Trenggalek,

Jl. Supriyadi No. 22, Trenggalek, Jawa Timur, 66319, Indonesia

Email: nugrohowahyu.wn93@gmail.com
}

\section{Angga Setiawan, M.Pd}

STKIP PGRI Trenggalek,

Jl. Supriyadi No. 22, Trenggalek, Jawa Timur, 66319, Indonesia

Email: anggasetiawan25.as@gmail.com

Bima Nur Romadhoni

STKIP PGRI Trenggalek,

Jl. Supriyadi No. 22, Trenggalek, Jawa Timur, 66319, Indonesia

Email: bimasajja@gmail.com 